\title{
WAYS OF IMPROVING STUDENTS' WRITING A RESEARCH PROPOSAL
}

\author{
Nguyen Thi Minh Hanh ${ }^{1}$
}

\begin{abstract}
Writing a research proposal is one of the crucial stages for students to get acquainted with solving their studying issues scientifically. Simultaneously, this creates inspirations for students to do scientific research. Writing a research proposal also requires a lot of knowledge and some skills that students have collected from other subjects and even from their daily lives. However, the survey of research proposal writing from 84 students of English language, 17 (2017 - 2021) showed that students made some common mistakes such as too broad topics, unclear research questions, poor literature review and writing style. These mistakes affected the students' ways of choosing research methods for their problems. This article presents mistakes that most of the students made and analyzes the factors causing these mistakes. It also presents practical ways to help students write better proposals and help them have more motivation and selfconfidence to do research activities.
\end{abstract}

Keywords: research proposal writing, students of English language, students' writing improvement.

\section{INTRODUCTION}

Learning how to write a research proposal is one of the subjects that second-year students of the English language study in the second semester. Writing a research proposal is a source of anxiety for most students who may feel lost in the face of the novelty of the process, pressured by time restrictions

\footnotetext{
${ }^{1}$ Quang Nam University

Email: hanhtky@gmail.com

Received date: $25^{\text {th }}$ May 2020; Revised date: $28^{\text {th }}$ June 2020; Accepted date: $21^{\text {th }}$ September 2020
}

and stressed by the prospective evaluation of their work [1]. However, it is essential to know how to write a research proposal because it helps students conduct research. As Best [2] puts it, no proper research can result from the absence of a designed proposal. The survey of 84 research proposals of 84 students of the English language, Course 17 at Quang Nam University showed some mistakes that students made. The causes and some suggestions will be presented with the hope of sharing some useful experiences with the teachers teaching Research Methodology. The research findings and ways of improving will be able to contribute to helping students spend their time more suitably on preparing a better research proposal.

\section{PREVIOUS STUDIES}

Writing a research proposal has been a difficult task for students. Therefore, many researchers have carried their studies to find out the reasons why students find challenging to write a good proposal and suggest some solutions. A number of studies have been done to find the reasons and solutions to help students write a good proposal.

Hadi [3] presented some key ideas which are worth learning by those undertaking undergraduate thesis so that they can start working on their proposal quickly. This study only suggested some ways to write a proposal without investigating any difficulties from the students.

Samaya and Suryadi [4] presented the results of using mind mapping to guide 25 students of the Economics Faculty of Tridinanti to write a research proposal. The results 
showed that students' writing skills of research proposal increased after being taught by using mind mapping learning models in cycle I, cycle II and cycle III. In this study, an experiment was carried out on applying the mind mapping into teaching students to write a proposal without telling us about the difficulties of students when they write a research proposal.

Xia and Luxin [5] explored how six graduate students of an English as a foreign language (EFL) program learned to write their master's thesis proposals in English in a graduate course. Data analyses showed that the students encountered in selecting a research topic, designing the proposal research, grasping the genre of the thesis proposal, and doing a critical literature review. The survey also suggested some coping strategies, namely negotiations with supervisors and interaction with peers to help students adjust themselves to the conventions of doing research and writing a thesis proposal.

Firza and Aisiah [6] investigated errors in the use of writing procedures when writing research proposals written by students taking courses in educational research methods in January-June semester of the academic year 2017/2018. The results of the study showed that errors that occurred in writing scientific papers were on the written systems (letters, words and sentences) and contents. This study listed specific errors in writing research proposals without suggesting the solutions.

There have been some writings in Vietnamese [7], [8] about how to write a proposal in writing a research proposal, but they are common guidelines for everyone who wants to do scientific research.

In conclusion, the previous studies showed that the researchers either analyzed the mistakes or suggested some ways when students wrote research proposals. Therefore, this study was conducted to find out some common mistakes and the reasons why students made the mistakes right after they finished their course of research methodol- ogy. Simultaneously, some ways of improving their writing research proposals were included.

\section{THEORETICAL BACKGROUND}

\section{A. Definition of a Research Proposal}

A research proposal is a "formal written plan which communicates ideas about a proposed study in order to obtain approval to conduct the study or to seek funding" [1].

The definition shows that a research proposal is to persuade others that a writer has a significant research project and that he/she has the work-plan to complete it. It also shows that a research proposal should contain all the main elements involved in the research process and include sufficient information for the readers to evaluate the proposed study.

\section{B. Components of a Research Proposal}

Regardless of whether the proposal is for a graduation paper or a master's thesis, a doctoral thesis or a high-level project, there is broad agreement that its content and structure are mostly similar. A research proposal includes six possible components: Title, Introduction, Literature Review, Methods, Results and Discussion, Conclusion and Suggestions.

1) Topic: Summarizes the main idea or ideas of the study. A good title contains the fewest possible words that adequately describe the contents and/or purpose of the research paper. If the title is too long, it usually contains too many unnecessary words. On the other hand, a title which is too short often uses words which are too general.

2) Introduction: Includes Rationale, Aims and Objectives, Research Questions, Scope of the Study, Significance of the Study, and Organization of the Study.

3) Literature Review: Includes Theoretical Background and Review of Previous Studies related to the research.

4) Methods: Includes Research Design, Research Methods, Data Collection and Data Analysis. 
5) Results and Discussion: Include the results of the research and discussions.

6) Conclusion and Suggestions: Include conclusions and solutions to the problem

\section{METHODOLOGY}

\section{A. Data Collection}

Data sources came from research proposals written by 84 students of the English language, Course 17. During their course of Research Methodology at the university, students were asked to write the components of a proposal and finish them at the end of the course.

\section{B. Data Analysis}

The aim of this study was to find out the mistakes students made in their writing research proposals, so the qualitative analysis played an important role. The qualitative analysis helped to find out the characteristics of writing mistakes from the students' proposals. In addition, quantitative analysis was so necessary because it helped to identify the number of students made writing mistakes and identify which mistake the majority of students made.

This study also adopted descriptive and analytic methods. The descriptive analysis was used to describe the common mistakes of students at Quang Nam University made in their writing. The analytic method was used to analyze the reasons why the majority of students had the same mistakes in their writing proposals.

\section{FINDINGS AND DISCUSSION}

After collecting and analyzing the data, the results are presented in different themes such as Common mistakes students made in their research proposals and the reasons causing these mistakes; Ways of improving students' writing a research proposal.

\section{A. Common Mistakes Students Made in Their Research Proposals and the Reasons Causing These Mistakes}

The survey of 84 research proposals showed that students made many mistakes in their writing. However, there were common mistakes such as too broad topics, unclear research questions, bad literature review and writing styles.

1) Mistakes in Identifying a Topic: The topic is the first indication of the content of the proposal and thus "should summarise, succinctly and precisely what the research is about", reflecting the nature and scope of the work [9]. However, the findings showed that 26/84 students had a too broad topic for their research. That made students have difficulties in collecting data for their study. For instance, the following topics "Early marriage and its consequences for Vietnamese adolescents", "Influences of Facebook on the learning activities of students at Quang Nam University", "How does Wrestling attract new fans around the world?", "The effects of traffic jam on the quality of life", "English communication skills in the 4.0 era of Vietnamese students", "Unemployment of students after graduation"... are the ones that have large scopes of study.

2) Mistakes in constructing research questions: A good research question is essential to guide the research paper, project or thesis. It pinpoints what the researchers want to find out and gives their work a clear focus and purpose [7]. As shown in Table 1, 66/84 students made mistakes in writing research questions.

\section{Questions were disordered}

Some students could identify the key parts of the study, such as problems, causes and solutions, but they could not put the questions in the logic order. For instance, with the topic "Common Grammatical Errors in Writing Sentences of the First-year English Major Students at Quang Nam University", the student should have made the question with three aspects in order: common grammatical 
Table 1: Mistakes in constructing research questions

\begin{tabular}{clc}
\hline Order & \multicolumn{1}{c}{$\begin{array}{c}\text { Mistakes in Constructing } \\
\text { Research Questions }\end{array}$} & Occurrences \\
\hline 1 & $\begin{array}{l}\text { Questions were disordered } \\
\text { Questions did not reflect the main } \\
2\end{array}$ & 24 \\
& $\begin{array}{l}\text { contents of the study } \\
\text { The number of questions was not } \\
\text { suitable }\end{array}$ & 14 \\
4 & Yes/No questions were used & 5 \\
& $\quad$ Total
\end{tabular}

errors, causes and solutions. However, students put the questions in an inappropriate order:

1. What are the common grammatical mistakes made by the first-year students in writing sentences?

2. What are effective solutions for students when making grammatical mistakes?

3 . What are the causes of these mistakes?

There were 24/84 students who put the research questions in wrong orders. It seemed difficult for some students to make the research questions. Although they could identify the main contents of the topic, they felt confused to give out questions. Some students did not master the rules that the orders of the questions were the logic parts of their study.

\section{Questions did not reflect the main contents} of the study

The topic summarizes the main idea or ideas of the study. The research question states the specific issue or problem that students will focus on. However, 23/84 students wrote questions that were not closely related to the topic. For example, a student wrote the following questions although she had a clear topic "Effective methods of learning grammar for the first-year students of English at Quang Nam University?"

1. What do you usually do to improve your English grammar?

2. Why do you choose to study English?
3. What do you think about the importance of English grammar?

Another student made the same mistakes with the topic "Advantages and challenges of the Internet in learning English of the firstyear English major students at Quang Nam University". Instead of making questions of advantages, challenges and solutions, the student made four questions as follows

1. What benefits do you have from the internet for your study and research?

2. What time do you use the internet to study in a day?

3. How did you learn English on the internet?

4. What is the negative effect of the internet on your learning?

These above ways of making questions point out that some students could not identify the objectives of the study or they did not have enough time to think about the questions, so the research questions did not reflect the main contents of the study.

The number of questions was not suitable.

Most students chose the topics with three issues needing solving: real situations, causes and solutions. Therefore, the most suitable numbers of questions for them were from three or four. However, some students made either two questions or more than five questions. For example, a student made two questions for the topic "Environment pollution at Tam Thanh Beach today."

1. How should people be aware of the protection of the marine environment?

2. What are the roles of state agencies in protecting the marine environment?

In another example, a student wrote nine questions for his topic "Benefits of learning English online for the second-year English major students at Quang Nam University":

1. Why is learning English online increasingly popular?

2. How is the English course online?

3. Is learning English online necessary for students? Why? 
4. Would you like to hear and understand what foreigners are saying?

5. Why will studying English well help you have a dream job?

6. What are the difficulties when you study English online?

7. What are the benefits of learning English online?

8. What should people who have not got the concept of learning English online do?

There were 14 students who made either two questions or more than five questions for their studies. The reason why they could not make better questions is that they did not attend the classes regularly. In addition, some of them did not listen to the guidance of making research questions from the teacher.

Yes/No questions were used.

A research question is the focus of a study and guides all stages of inquiry, analysis and reporting. It usually begins with who, what, why and how [10]. Although students knew that, five students made mistakes. For example, the student wrote two yes/no questions for his topic "Possible factors cause unconfidence in communicating with foreigners of the second-year students of English at Quang Nam University":

1. Are you worried or scared when communicating with foreigners?

2. Do you think your knowledge is enough to communicate with foreigners?

Or, another example of Yes/No question in the study with the topic "Using pictures inspires students to learn vocabulary for the first-year English major students at Quang Nam university." Do you think learning vocabulary is important in studying English?

The students who made mainly yes/no questions in their research questions did not pay attention during their lesson, or they forgot what they learnt.

3) Mistakes in Review of Previous Studies related to the research: A literature review is by far an important section of any research paper. This tells readers how much time and effort the author has spent towards
Table 2: Mistakes in constructing research questions

\begin{tabular}{llc}
\hline Order & $\begin{array}{l}\text { Mistakes in Writing Review of } \\
\text { Previous Studies related to the } \\
\text { research }\end{array}$ & \multicolumn{1}{c}{ Occurrences } \\
\hline 1 & $\begin{array}{l}\text { Previous studies were not closely } \\
\text { related to the contents of the study }\end{array}$ \\
& $\begin{array}{l}\text { Numbers of previous studies were } \\
\text { not suitable }\end{array}$ & 15 \\
3 & $\begin{array}{l}\text { There were no conclusions of } \\
\text { previous studies }\end{array}$ & 28 \\
& $\quad$ Total
\end{tabular}

understanding the problem and investigating the work done so far [11]. For students, this part is the most difficult one. As required by the course, students had two weeks to finish this part of the research proposal, but they finished later. The findings (Table 2) showed that 54/84 students made mistakes in writing the review of previous studies related to the research. Some students listed all of the previous studies which they could search or read and put all of them in their writing. Some students wrote and analyzed only one or two previous studies because they could not find out any materials for their title. The most popular mistake in writing the previous studies was that students did not find out the differences and similarities from the previous studies compared to their topics. Therefore, they could not identify research gaps for their topics.

4) Mistakes in writing styles: As showed in Table 3,70/84 students made mistakes in their writing styles. They had a lot of grammatical mistakes and used speaking style in their writing.

Grammatical mistakes The findings showed that 54/84 students made grammatical mistakes in their writing. Firstly, many students used incorrect tenses for their writing, or they made wrong sentences. For example, they could not make a research question such as "How to improve 
Table 3: Mistakes in constructing research questions

\begin{tabular}{clc}
\hline Order & Mistakes in writing styles & Occurrences \\
\hline 1 & Grammatical mistakes & 54 \\
2 & Using speaking style & 16 \\
& Total & $\mathbf{7 0 / 8 4}$
\end{tabular}

French listening skill?" or "How technology 4.0 brings benefits to students?"

Secondly, they were confused about using parts of speech such as singular or plural nouns, linking words, adjectives. Thirdly, they misused punctuation marks and relative pronouns. For example, in the Introduction of the topic "Difficulties in learning French listening skills for the first-year English major students at Quang Nam University", a student wrote: "When learning a language there are four skills and listening skills that are considered to be the most difficult skill for students studying foreign languages at Quang Nam University. It requires constant training hard work; listening is a process where the listener understands a message that helps her master communication. If they do not understand it they will be less likely to respond effectively". In this paragraph, the student made many mistakes of using punctuation marks and relative pronouns. Besides that, her ideas were not clear and logic.

\section{Using Speaking Style}

Students need to use the academic words or British writing style for their writing. However, they used a lot of expressions in speaking, or they wrote in Vietnamese expressions. For example, many students used the phrase 'As you know' in their writing. Another example for the Vietnamese expressions from the part of Introduction with the research topic "Difficulties of the first-year English major students at Quang Nam University when they communicate with foreigners":

"Come to Quang Nam University, is a firstyear University major student. It is difficult to communicate because they are so accustomed to traditional teaching and learning methods with a passive approach in high school. The high students only focus on learning vocabulary, structure and grammar without focusing on listening and speaking skill. Study too much theory and practice less, so students are not confident in speaking English well, and it lasts when they become foreign language students."

Some students did not practise using academic writing style. In addition, they did not spend time reading materials to learn how to use the academic writing style.

\section{B. Ways of improving students' writing a research proposal}

Students will have better research proposals when they master the theory of writing parts of the proposal. Booth et al. [3] suggested some ways of identifying a topic and making questions. Some suggestions are drawn from the teacher who taught Research Methodology. There are also some ways for students to improve their writing styles via some useful websites.

1) Ways of identifying a topic: According to Booth et al. [3], there are two stages to choose a topic for research.

Stage 1: Students should find a topic in a general writing course

Students can start by listing as many interests as they can that they would like to explore. Then, they can choose the one or two that interest them most from the list of topics. After that, in the library, they can look up their topic in a general bibliography and skim the subheadings. They can use subheadings for ideas of how others have narrowed their topic. On the internet, they can google their topic, but they should not surf indiscriminately. They also use Wikipedia to find ideas and sources, but they should always confirm what they find in a reliable source. When they know the general outline of their topic and how others have narrowed it, they should 
try to narrow theirs. They can browse through journals and websites until the topic becomes more clearly defined.

Stage 2: Students should make a focused topic from a broad one

A topic is probably too broad if students state it in four or five words. So, they must narrow it by adding words and phrases.

Ex: Broad topic: Free will in Tolstoy

Focused topic: The conflict of free will and inevitability in Tolstoy's description of three battles in War and Peace [3].

2) Ways of writing research questions: Once a focused topic is made, students can start with the standard journalistic questions: who, what, when and where, but they should focus on how and why. To engage their best critical thinking, they should systematically ask questions about their topic's history, composition and categories. Then they can ask any other questions they think of or find in their sources. They can record all the questions, but they should not stop to answer them even when one or two grab their attention. Students can also look for internet discussions on their topic. They should record questions that spark their interest. They can post questions on the list if they are specific and narrowly focused. When students run out of questions, they can evaluate them, because not all questions are equally good. Finally, they should look for questions whose answers might make them think about their topic in a new way. They should avoid questions such as Yes/No questions because the answers for this kind of question are the settled fact that they could just lookup. They also should not use questions beginning with How many. For example, How many black cats slept in the Alamo the night before the battle? The answers for this kind of question are dead ends. It is a question that's probably not worth asking.

They should use questions asking how, and why because these questions invite deeper thinking than who, what, when, or where, and deeper thinking lead to more interesting answers.

Students should point out the objectives of their study. Basing on the objectives, they can make better research questions and can decide the number of questions. However, there should be at least three questions for a topic and less than five questions. The orders of the questions should follow the orders of the objectives.

3) Ways of Writing Review of Previous Studies related to the research: It takes students much time to write previous studies, so students should spend more time reading materials, books or surfing the internet to collect the necessary information for their topic. They can use the keywords in relevant online databases such as Google Scholar, PubMed to search for information. After the relevant literature has been reviewed, it should be organized thematically or chronologically [12].

The number of previous studies depends on the popularity of the topic, but students cannot mention only from one to two previous studies. Moreover, they should include a comparison and contrast of different studies. Finally, they must point out the main gaps that needed to be worked upon.

4) Ways of Overcoming Mistakes in Writing Styles: To overcome grammatical mistakes, students should use Spelling and Grammar on Microsoft Word or the website Grammarly.com after their typing. They can self - correct some mistakes of vocabularies, sentences, punctuation marks. Besides that, they can use websites such as Grammar Flip.com or dailygrammar.com to practise their grammar because these websites provide them with a lot of grammatical exercises.

Students can use the Four Square Writing Method (FSWM) to improve their writing paragraph. According to Bartholomae et al. [2], FSWM is a method that uses graphic organizer in helping students to organize facts, thoughts and ideas. The main principles of FSWM are topic box, reasons, supporting details, vivid language, and conclusion. The 
Topic box consists of a short sentence or phrase stating what students' paragraph or essay will be about. Reasons are directly related to the topic. Supporting details must support the topic and give more explanation, and description of the topic discussed. In the discussion of vivid language, students are allowed to work on their word choice and their voice. They can use five senses to elaborate the writing and express emotion by using adjectives. The design of FSWM can be seen in Figure 1.

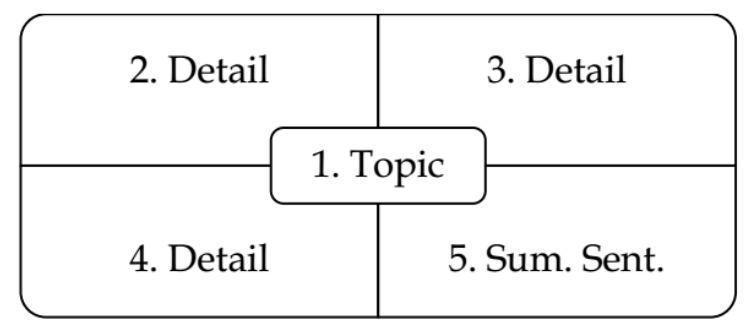

Fig. 1: The design of FSWM

\section{CONCLUSION}

With the aims of finding out the mistakes and causes from the research proposals written by students of the English language, course 17 at Quang Nam University, the survey showed that there were four groups of mistakes that students of English language, course 17 made during their writing the research proposals. They were mistakes in identifying the topic, writing research questions (disordering the questions; questions do not reflect the main contents of the study; numbers of questions are not suitable; using Yes/No questions), reviewing of previous studies related to the research (previous studies are not closely related to the contents of the study; the number of previous studies are not limited; there are no conclusions of previous studies), and writing styles (grammatical mistakes; using speaking style). There were some reasons why the students made some mistakes in their writing.
Firstly, the students did not master the rules or the theory of writing a proposal. Some students did not spend enough time preparing the ideas for their writing. Secondly, the results of checking class attendance during the researcher's teaching showed that some students did not attend the class regularly, so they did not listen to the lessons. Thirdly, many students made grammatical mistakes and used speaking style because they did not spend time practising grammar exercises. Besides that, they did not use software or websites to check their grammar and spelling. They did not read more to learn the academic writing style.

From the students' mistakes, the paper presents some solutions suggested by Booth et al. [3] and other researches. The results of the survey can help students know some common mistakes they might make in their writing a proposal. Moreover, some useful ways of improving their writing are suggested with the hope that students will write their proposals better.

\section{REFERENCES}

[1] Onwuegbuzie Anthony J. Writing a Research Proposal: The Role of Library Anxiety, Statistics Anxiety, and Composition Anxiety. Library \& Information Science Research. 1997;19(1):5-33.

[2] Singh U. Developing research proposal. 4th; 2020. Available from: https://wikieducator.org/developing_research_proposal [accessed 10th March 2020].

[3] Hadi M J. Writing a Research Proposal in English Language Education, Undergraduate Thesis writing workshop for students of Engish language education. University of Mahdlatul Wathan Mataram, Mataram; 2016.

[4] Samaya D, Suryadi E. Improving Writing Skill of Research Proposal Through Mind Mapping of Economics Faculty Students of Tridinanti, University Palembang, Advances in Social Science, Education and Humanities Research. International Conference on Progressive Education. 2019;422.

[5] Xia W, Luxin Y. Problems and Strategies in Learning to write a Thesis Proposal: A Study of Six M.A Students in a TEFL Program. Chinese Journal of Applied Linguistics (Quarterly). 2012;35(3).

[6] Firza F, Aisiah A. Error of Proposal Writing by Students, Advances in Social Science, Education and 
Humanities Research. Asian Education Symposium. 3rd. 2018;253.

[7] Lưu Hà Chi. Hướng dân cách viêt đề cương nghiên cúu khoa học chi tiết. 10/1/2020. Truy cập từ: https://luanvanviet.com/de-cuong-la-gi-huongdan-viet-de-cuong-nghien-cuu-khoa-hoc [ngày trích dẫn 15/3/2020].

[8] Hoàng Hà. Xây dụng đề cương nghiên cứu khoa hoc. 2019. Truy cập từ: https://yhocbandia.vn/xaydung-de-cuong-nghien-cuu-khoa-hoc. [ngày trích dẫn 9//3/2020].

[9] Baker Michael J, Foy A. Business and Management Research. 2nd Edition, Helensburgh, Scotland: Westburn Publishers; 2008.

[10] Abao J. What is the difference between a research question and a research paper title. 2020. Available from: https://www.quora.com/What-is-the-differencebetween-a-research-question-and-a research-paper- title [accessed 15th March 2020].

[11] Piyush R. How can I write the previous studies in a literature review of a research paper. 2020. Available from: https://www.quora.com/How-can-Iwrite-the-previous-studies-in-a-literature-review-of-aresearch-paper [accessed 15th March 2020].

[12] Booth W.C, Colomb G.G, Williams J.M. The Craft of Research. 3nd Edition. The Universtity of Chicago Press; 2008.

[13] Sachdev R. How to write the literature review of your research paper. 2020. Available from: https://www.editage.com/insights/how-to-write-theliterature-review-of-your-research-paper [accessed 15th March 2020].

[14] Bartholomae M, Sekyra S, Sibigtroth K. Bring 4Square Writing to Life. Teaching and Learning Company; 2011. 